\title{
Capacity Building in Public Sector Organisations
}

\author{
SEEMI WAHEED
}

\section{INTRODUCTION}

During the last two decades the world has experienced a major transformation in thinking on the role of government in provision of services and socio-economic development. This change in thinking has come about as a result of the inability of two major philosophies of production - capitalism and socialism - to redistribute resources for the improvement in the living condition of the masses. Both the philosophies have shortcomings. Capitalism encourages entrepreneurship and growth, but it also creates extreme economic disparities leading to poverty. Socialism in its attempt to create an egalitarian society curbs and stifles entrepreneurship, leading to discontentment and economic inefficiencies.

Developing countries have followed, by and large, a mix of these philosophies but the result has not been encouraging in most of the cases. Economic distortions and inefficiencies have been the common outcome. In addition, human development indicators and the quality of life in these countries has fallen far below the minimum acceptable standard. Inequitable distribution of resources is attributed to the absence of a participative and democratic political structure on the one hand, and mismanagement of resources and the absence of a facilitative administrative structure on the other. The latter attribute is now commonly termed as poor 'governance' of resources.

The success, in terms of growth and development, of the Newly Industrialised Countries (Korea, Taiwan, Singapore, Malaysia, Hong Kong) was attributed to the reforms in civil service [World Bank (1993)] irrespective of whether these were authoritative or democratic regimes [Boeninger (1992)]. It was, thus, demonstrated that the essential element in the economic growth in these countries was the application of rule of law, transparency, accountability and strengthening of institutions rather than any particular form of government.

Governance, as understood in common parlance means enabling or facilitating an environment that promotes public-private partnership for equitable economic

Seemi Waheed is Deputy Director (Academics), Pakistan Administrative Staff College, Government of Pakistan, Lahore. 
growth [Edralin (1996-97)]. If that be the goal of governance, the effectiveness of government will be measured in terms of the achievement of the goal.

The effectiveness of any organisation is established when the right goals are selected and achieved. For achieving defined goals, it is essential that organisations design an organisational structure that is facilitative in the achievement of goals. The focus is on developing enabling environments for employees which, in turn, means developing a human resource management system that is oriented to achieving goals. The Human Resource Management System (HRMS) comprises human resource planning, recruitment/selection, training and development and performance appraisal. Each of the aspects has a backward and forward linkage which is based on the assessment of an organisations' present and future needs.

It is a fact that public organisations, whether departments, semi-autonomous or autonomous bodies, and authorities, have archaic organisation structures, procedures, rules and regulations and above all 'non-enabling attitudes'. All these do not promote development nor encourage public-private partnership. The inertia of the public bureaucracy is so obvious that these respond slowly to the changes in the external environment.

As a result, the human resource management system which includes federal and provincial Public Service Commission (FPSC) (recruiting organisation) and the Establishment Division ${ }^{1}$ (responsible for the placement, training, promotion, transfer etc.) in public sector, has responded slowly to the changes in the socio-economic and technological environment. Consequently, these organisations have neither introduced new subjects nor revamped the syllabus of competitive examinations. The pre-entry and in-service training systems also remain less changed. In fact, there is little effort to provide new skills (computer, interpersonal, negotiation etc.) and attitudes (optimistic, non-complaining, helpful, cooperative etc.) to employees at middle and operating level. Keeping in view the required restructuring of public organisation for capacity building the paper will focus on (a) establishing goals in public sector organisation (b) organisational structure (c) human resource management system.

\section{REVIEW OF LITERATURE ON CAPACITY BUILDING}

Literature on governance invariably discusses capacity building. Capacity building has a broader scope than institution building, because in addition to concern for human resources and organisation, it covers the overall environment within which organisations operate and interact. In includes, for example, working of the labour market, which determines how efficiently the human resources are allocated among alternative uses; concern for the ability of public sector institutions to finance recurrent budgets and to provide adequate levels of salary to hire and retain qualified and trained

${ }^{1}$ FPSC is the main recruiting organisation for civil jobs. Establishment Division, another HRM organisation, deals with the placement, training, transfer, promotion etc. of all the civil service employees. 
staff (World Conference on Governance, held in Manila from 31 May - 4 June 1999). Apparently, the capacity building approach is specific, however it needs to consider the overall environment in which the organisation is operating and the need to make rules, regulation and procedures coherent with the achievement of goals.

Capacity can be defined as capability to perform the specific assigned task effectively and efficiently on a continuous basis. 'Capacity' is like a container having some volume. The container can be filled to the extent of its volume. However, human capacity to perform assigned specific tasks efficiently and effectively is not fixed. It can be enhanced and improved through training, interaction and exposure to new methods, skills and opportunity to use acquired skills.

According to Management Development and Governance Division/United Nations Development Programme (MDGD/UNDP), capacity building for public service requires improvement in the ability to identify problems for public action, assess options for responding to these problems, formulate policies that constructively address these problems, implement activities required by the policies and sustain such activities over sufficient time to have an impact on conditions for economic and social development.

Increasing efficiency and effectiveness has been the goal of Taylorism (classical school of management) and the Weberian School (structuralist). The ultimate goals of increasing efficiency, for classical and structuralist schools have been maximisation of profits, in case of private firms, and maximisation of service in case of a public organisation. [Sharitz and Ott (1987)].

The inability of State apparatus to maximise its goals is influenced by the following facts: [Boeninger (1992)].

- Authority: The political and institutional requirement for establishing authority should not be taken for granted. Political conflicts often result in strategies explicitly designed to hinder the exercise of authority. Society cannot function without impartial rules for all citizens. In order to avoid arbitrary actions legal limits to authority need to be established.

- Problem-solving: Identifying problems and issues, formulating options to solve these and mobilising resources through the tax system required suitable institutional channels that respond to conflicting demands.

- Conflict Resolution: Political and social conflicts can adversely affect development. What is needed at the level of strategic planning and political action is the ability to channel and resolve such conflicts. This requires sustainable institutional channels and a framework of viable options.

- Implementation: Economists and politicians tend to take it for granted that once decisions are made they will be effectively translated into operational realities. In fact, administrative bottlenecks in the government and the private sector may jeopardise government programmes. These constraints 
may involve lack of managerial know-how or deliberate political obstruction. This phase of policy-making process provides ample opportunities for impending and delaying public polices. Private sector initiatives, too, may be blocked for ideological reason. Without effective implementation capability, a stalemate ensues, or unintended effects frustrate the government's development goals.

Cohen also developed a framework for analysing capacity building issues. His framework consists of five dimensions: (a) targeted personnel capacity (i.e., personnel who carry out critical or high priority government functions such as public sector managers, professionals and technicians) (b) capacity building stages (beginning with anticipating, planning and advocating manpower needs; and utilising effectively the institution's emerging cadre of skilled personnel; training and upgrading skills through in-service programmes, and ending with promoting an attractive public service through leadership, strategies and rules); (c) training capacity; (d) external institutional, manpower, and support system (e.g. obtaining support from institutions, in charge of training, managing, and retention of manpower, institutions that play a role in supporting capacity building efforts; information, communications and institutional coordination systems, support by political leaders, decision-makers and stakeholders and budgetary and financial resources); and (e) public sector task environment factors that affect institutional efforts to recruit, effectively use, and retain skilled personnel.

Focussing on capacity building, Cohen, Boeninger and others have not mentioned goal setting or developing mission statement in public sector organisation, which is the starting point for building capacity. It is generally observed that public sector organisations do not generally have a written mission statement from which goals and objectives can be derived. For example, public sector training institutions do not have an organisational mission statement, however, they have goals, which are stated as objectives. ${ }^{2}$ Similarly, ministries and divisions lack mission statements. Majority of the activities carried out, are run on the treadmill" without due cognizance to identification of problems and its resolution as stated by Boeninger. Partly, this is owing to lack of political commitment to identify problems and resolve them by building capacity. The paper will, therefore, focus on this aspect.

\section{METHODOLOGY}

The paper will be largely conceptual and theoretical. It would draw upon the literature on capacity building in public sector organisation. The approach used will be based on a priori reasoning. The sources of information would be mainly secondary.

\footnotetext{
${ }^{2}$ There is hierarchy of mission, goals and objectives. Mission statement gives the statement of existence of organisation in a particular business. Goals are desired ends and objectives are specific short term, verifiable measurable ends to be achieved in a given time frame.
} 
The model of capacity building will be developed for public sector organisation. The variables of the model are: (1) mission statement, (2) goals and objectives, (3) organisational structure, (4) HRMS comprises (i) recruitment, (ii) training, (iii) performance evaluation, (iv) incentives.

The mission statement is the independent variable on which all the other variables and sub-variables are dependent. It is assumed that once the organisations formulate a clear mission statement, goals and objectives it would be relatively easier to develop appropriate structures and HRMS to achieve goals.

\section{A STRATEGIC MODEL FOR CAPACITY BUILDING IN PUBLIC SECTOR}

Why do we need a model for capacity building in public sector organisation? On the one hand the model will facilitate the identification of the missing links or gaps in capacity building in public service; on the other, it will also help in identification of the variables of capacity building that lead to effective and efficient performance. The variables of the model are mission statement, goals, organisation structure, human resource management system, output and service. All these operate in a macro environment which comprises the political, economic, social and technological environment.

Following is the generic model for capacity building for public sector organisation:

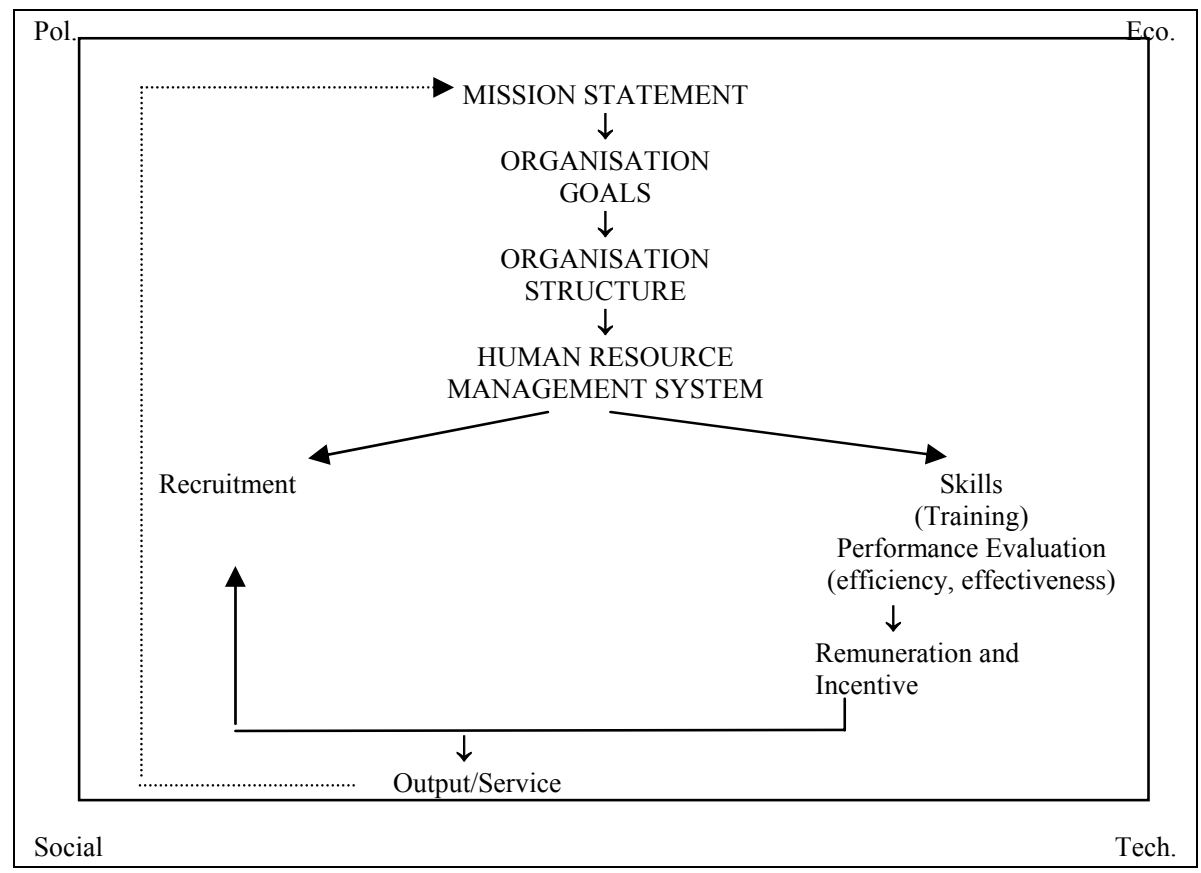

Fig. 1. 
The above model can be applied to specific public sector organisation (ministry, division, department, semi-autonomous body etc.) with related modifications, if any, required.

\section{Mission Statement}

The first element of the model is developing a mission statement for public sector organisation. The mission statement explains what the organisation is and what it seeks to achieve. The mission exists not as a concept but as a statement. It gives identity and direction to the organisation. The development of the mission statement has three dimensions, (1) shared values, beliefs and vision (2) formulation of goals, objectives and methods of achieving and (3) performance measurement, communication and feedback, incentives [Kiggundu (1989)].

Often, in the literature of organisation management, the mission and the goals are used interchangably. However, these have conceptual differences. A mission statement, as mentioned, gives the broadest statement of an organisation's strategy. This is more stable and does not change so rapidly. From the mission statement a set of goals (one, two or more) are derived, and from these the objectives (specific, measurable, achievable, realistic and time-bound) are spelled out.

In the absence of a mission statement, neither goals and objectives can be formulated nor can capacity be enhanced. Without it, the performance evaluation of an organisation and its employees would be like taking a shot in the dark. It is, therefore, essential that public sector organisations state their missions and fix their goals. As an example the mission for an apex training organisation in the public sector could be:

(a) To enhance the requisite management competencies of senior managers from public/private sector to deal with future challenges.

(b) To remain governments' preferred supplier of policy advice.

(c) To provide enriching and satisfying place to trainees and its employees.

(d) To inculcate work ethics for promotion of good governance.

From this mission statement the following goals can be derived:

1. To carry out training need assessment (TNA) for public service for middle and top level management with the support of Establishment Division.

2. To continuously improve quality of courses, facilities and human resource.

3. To conduct short specialised courses (in addition to long course) for middle and top management level in public and private sector.

4. To train staff at all levels in the organisation to handle their given jobs/assignments and provide appropriate incentives to motivate people to undertake additional assignment.

The above mentioned goals will provide guidelines for developing objectives for a given time period: 
1. To undertake TNA for the middle and top management of the 'training organisation'.

2. To update/develop job descriptions/specification of the employees of Pakistan Administrative Staff College (PASC) at operational, middle and top level, and identify the deficient areas requiring improvement.

3. To provide both on-the-job and of-the-job skill oriented training to those who are deficient in given skills.

4. To conduct $X$ number of courses in, say, quality improvement, or computer skills. IT management, leadership, negotiation skills.

5. To organise two seminars of national/international level on 'current topics'.

6. To purchase equipment for the classroom in 1999-2000.

7. To purchase $\mathrm{X}$ number of books, journals, magazines for the library in specialised areas.

8. To equip the library with on-line information system through Internet facility in 1999-2000.

The formulation of the mission statement, goals and objectives is summarised in Fig.2.

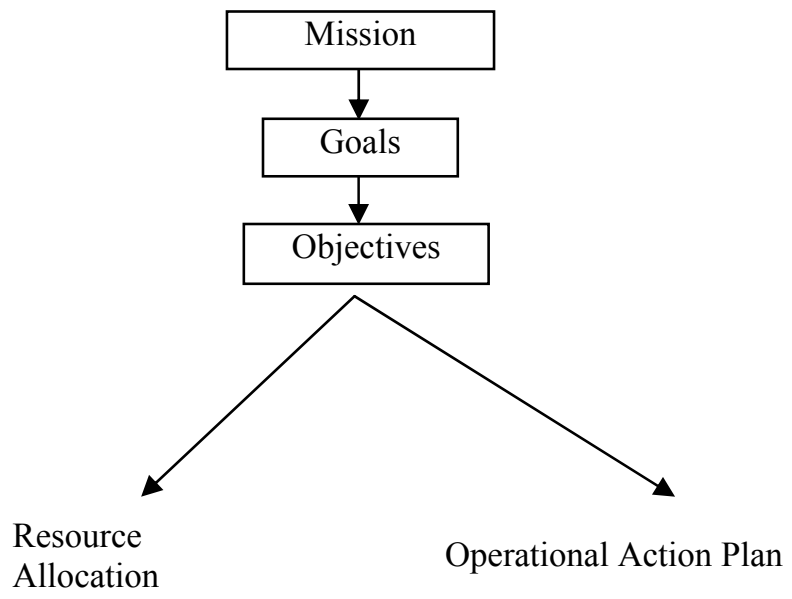

Fig. 2.

\section{Structure}

The structure of an organisation is designed in a way to facilitate the achievement of its goals and objectives. Organisational structure refers to the ways 
that tasks and responsibility are allocated to individuals and the way individuals are grouped in offices, departments and divisions. An organisational structure could be flat or tall, centralised or decentralised, participative or authoritative, which depends on what goals the organisation is pursuing [Wright et al. (1996)].

Government structure appears as one monolithic structure in which all departments, semi-autonomous and autonomous bodies have more or less a similar structure, irrespective of what particular 'business' the organisation is pursuing. Hierarchy, the chain of command and centralisation, are generally the elements that are emphasised in a public sector organisation. This is so because operational skills (information, transmission, interpersonal abilities, computer facility etc., to name a few) are weak. Therefore decisions have to be made even for operating tasks, at the higher level.

Decentralisation is often prescribed for public sector organisations, especially in the execution of development projects like health, education, agriculture, irrigation etc. through local government initiative which has met with reported success in the execution of such projects. [Bhatt et al. (1987).]

However, effective decentralised organisational structure requires appropriate skills of subordinates ${ }^{3}$, clarity of delegation of authority, clarity of plans/objectives, communication technique, amount of personal contact required and feedback/ control. It also requires positive behaviour (cooperation, willingness, noncomplaining, sharing work information etc.) of subordinates to accept responsibility and willingness to take risks within certain limits.

\section{Human Resource Management System (HRMS)}

It goes without saying that the main competitive advantage of any organisation is its human resource. Therefore, special focus has to be given to all its sub-systems comprising, recruitment, training (skills), performance evaluation, remuneration and incentives (Fig.1 gives the interrelationship of HRMS with output and mission statement).

The need for human resource planning may not be readily apparent. However, an organisation that does not do human resource planning may find that it is not meeting its personnel requirement or its overall goals effectively. Human resource planning has four aspects:

(a) Planning for future needs by deciding how many people with what skills the organisation will need.

(b) Planning for future balance by comparing the number of needed employees to the number of present employees who can be expected to stay with the organisation.

${ }^{3}$ These skills have to be identified for the jobs of employees of respective organisations. However, general skills could be divided into technical skills and interpersonal skills. The technical skills would be: IT skills, information processing, problems identification, problem resolution, analysis etc. Interpersonal skills would be: ability to communicate with empathy, courtesy. 
(c) Planning for recruiting and laying off employees, and;

(d) Planning for development of employees to make sure the organisation has a steady supply of experience and capable personnel.

The number of employees to be hired and trained would be determined by these aspects of planning but such an organised and careful human resource planning is absent in public sector organisation. Much of human resource planning is based on rule of thumb.

\section{Recruitment and Training}

Each year the civil service recruitment system attracts qualified people from all over the country who are screened through a competitive examination, interview and psychological testing. There is a general for these tests. It includes almost all the social sciences and selected science subject. This syllabus needs to be updated and revised for holding the competitive examination.

Successful candidates are assigned Occupational Groups ${ }^{4}$ on the basis of marks obtained. Approximately, 100 selectees undergo a Common Training Programme (CTP) at the Civil Service Academy for eight months each year. After which they join specialised training institutions. They also undergo on-the-jobtraining through attachment to a department for a certain period of time, after which they are inducted into regular service.

The public (civil) service has an elaborate system of training at the middle and top management level. This includes pre-entry training at Civil Service Academy, middle level training at National Institute of Public Administration (one each in the four provinces) and senior management training at Pakistan Administrative Staff College. A vast majority of employees working at the operative level (BS-1 to BS-16) receive little or no formal training to handle the assigned jobs. These employees work in local government and rural development departments, the departments of health, agriculture, planning and development and education at the provincial and federal levels.

Most of the government jobs, have no job description or specification. Training even at the top and middle levels is done without TNA. At the operational level, there is neither TNA nor training. And most training and development is without analysis of jobs which is a pre-requisite for TNA to identify the areas in which training is required. Training in public service requires comprehensive and detailed analysis at all levels and for all jobs to build capacity.

\section{Compensation and Performance Evaluation}

Government jobs are the most secure jobs whether one delivers output/service or not. One keeps receiving compensation and annual increment. Increment or raise in salary is not contingent on performance. Public personnel receive salary,

${ }^{4}$ The civil service comprise twelve Occupational Groups which are; District Management Group, Office Management Group, Income Tax, Customs and Excise, Police Service, Railways, Accounts Group, Foreign Service, Secretariat, Information. 
allowances etc. in 22 basic pay scales (BS). BS-1 includes such diverse jobs as peons, sweepers, janitorial staff, bearers, security guards etc. The salary for all these jobs is the same (Annex-1). Similarly there are jobs in BS-17 which are as diverse as assistant superintendent police, computer programmer, researcher, doctor, engineer, administrator etc. The salary for all these jobs is the same. This, illustrates that the salary structure in public service is not commensurate with the nature of the job and it is considered to be low as compared to that in the private sector.

Performance evaluation is the most bizarre in public service. From BS-16 to BS-22, for all jobs there is one performance evaluation form Annex-II). Performance variables on which employees are assessed are ambiguous and have little relevance with the output of the employee. Objectives to be achieved by the employee during a given period are not known. At the end of the period (year) assessment is based on a general criteria, e.g., intelligence, integrity, quality of output etc. and not on the achievement of objectives. As pointed out, jobs in public service are diverse, therefore, performance (efficiency and effectiveness) need to be assessed on the basis of achievement of objectives outlined for each job.

\section{CONCLUSION}

Capacity building in organisations requires the formulation of a mission statement, goals and objectives. It is a pivotal activity, as far as the development of organisational structure and HRMS is concerned.

It is a fact that goals and objectives in public sector organisations are elusive, and seldom institutionalised. As a result employees do not share organisational values and beliefs which are necessary to achieve its mission and goals.

The model for capacity building (Fig.1) helps understand the importance of each step and variable in capacity building for organisation. However, constraints to the application of models need to be taken into consideration. Specific constraints in application of this model in a developing country situation are: (1) lack of commitment of leadership to improve organisational capacity; (2) short-term and urgent (may be not important) matters take priority over important ones; (3) interference in routine matters by political leaders; (4) organisational procedure, rules etc. are tampered for personal selfish interests; and (5) non-professional attitude dominating public sector organisation. Even, if 20 percent $^{5}$ of the constraints identified are overcome, in a given time frame, considerable improvement in efficiency can occur.

There is need to redesign the performance evaluation system. However, in the management of HRMS the important measures to be taken are: updating and modifying the recruitment system; job analysis of all jobs in public sector; conducing TNA and imparting training to undertake assignment according to the requirement of job.

Each variable of the model presented requires further research in the context of the respective organisation for giving specific recommendations.

${ }^{5} 20$ percent is based on 20-80 Pareto Rule. According to the rule 80 percent of the wealth of the world is in the hands of 20 percent of people. Similarly 20 percent. of people really work to give 80 percent of the output. 
Annexures

\section{Annexure I}

Basic Monthly Pay Scales

\begin{tabular}{|c|c|c|c|c|c|}
\hline Pay Scale & $\begin{array}{c}\text { Minimum } \\
(\mathrm{Rs})\end{array}$ & $\begin{array}{l}\text { Increment } \\
(\mathrm{Rs})\end{array}$ & $\begin{array}{l}\text { Number of } \\
\text { Pay Points }\end{array}$ & $\begin{array}{l}\text { Maximum } \\
(\mathrm{Rs})\end{array}$ & Sample Position \\
\hline BPS-1 & 1,245 & 35 & 16 & 1,770 & Sweeper \\
\hline BPS-2 & 1,275 & 44 & 16 & 1,935 & Quasid \\
\hline BPS-3 & 1,320 & 50 & 16 & 2,070 & Daftri \\
\hline BPS-4 & 1,360 & 58 & 16 & 2,230 & Dispatch Rider, Driver \\
\hline BPS-5 & 1,400 & 66 & 16 & 2,390 & Urdu Typist \\
\hline BPS-6 & 1,440 & 73 & 16 & 2,535 & \\
\hline BPS-7 & 1,480 & 81 & 16 & 2,695 & Telex Operator \\
\hline BPS-8 & 1,540 & 88 & 16 & 2,860 & \\
\hline BPS-9 & 1,605 & 97 & 16 & 3,060 & \\
\hline BPS-10 & 1,660 & 107 & 16 & 3,265 & \\
\hline BPS-11 & 1,725 & 116 & 16 & 3,465 & \\
\hline BPS-12 & 1,830 & 130 & 16 & 3,780 & Stenotypist \\
\hline BPS-13 & 1,950 & 144 & 16 & 4,110 & Accountant \\
\hline BPS-14 & 2,065 & 161 & 16 & 4,480 & \\
\hline BPS-15 & 2,190 & 177 & 16 & 4,845 & Stenographer \\
\hline BPS-16 & 2,535 & 197 & 16 & 5,490 & Admin Officer \\
\hline BPS-17 & 3,880 & 290 & 13 & 7,360 & Private Secretary \\
\hline BPS-18 & 5,085 & 366 & 11 & 8,745 & Agronomist \\
\hline BPS-19 & 7,750 & 385 & 11 & 11,600 & $\begin{array}{l}\text { Deputy Secretary, } \\
\text { Senior Agricultural Economists }\end{array}$ \\
\hline BPS-20 & 9,195 & 440 & 11 & 13,595 & $\begin{array}{l}\text { Economic Consultant, } \\
\text { Joint Secretary }\end{array}$ \\
\hline BPS-21 & 10,190 & 545 & 11 & 15,640 & Senior Joint Secretary \\
\hline BPS-22 & 10,900 & 610 & 11 & 17,000 & Secretary \\
\hline
\end{tabular}


Annexure II

CONFIDENTIAL

\section{GOVERNMENT OF}

Name of The Ministry/Division/Department/Office) Name of Service.

\section{PERFORMANCE EVALUATION REPORT}

FOR THE PERIOD FROM $19 \quad$ TO 19

\section{PART I}

1. Name (in block letters):

2. Date of birth: Date of entry in Service:

3. BPS, with present pay:

4. Post held during the period:

5. Academic Qualifications:

6. Knowledge of languages (Please indicate proficiency in speaking (S), reading (R) and writing (W):

7. Hobbies:

8. Training Received:

\begin{tabular}{l|c|c|c}
\hline \multirow{2}{*}{$\begin{array}{l}\text { Name of course } \\
\text { attended }\end{array}$} & \multicolumn{2}{|c|}{ Dates } & \multirow{2}{*}{$\begin{array}{c}\text { Name of institution } \\
\text { and country }\end{array}$} \\
\cline { 2 - 3 } & From & To & \\
\hline & & & \\
\hline & & & \\
\hline & & & \\
\hline
\end{tabular}

9. Job Description (Set out broadly in order of importance the main duties performed. Also mention any special work assigned during the period): 
10. Period served:
(a) in present post
(b) under reporting officer.

11. Date of last annual medical checkup.

Signature

The rating in Parts II \& III and IV should be recorded by initialling the appropriate box. The ratings denoted by alphabets is as follows:

'A1' (Very Good), 'A' (Good), 'B' (Average),

'C' (Below Average), 'D' (Poor).

For uniform interpretation of qualities listed in these parts, two extreme shades are mentioned against each item. Please see para 7 of instructions.

PART II

\begin{tabular}{|c|c|c|c|c|c|c|c|}
\hline \multicolumn{8}{|c|}{ PERSONAL QUALITIES } \\
\hline & & A1 & $\mathrm{A}$ & B & $\mathrm{C}$ & $\mathrm{D}$ & \\
\hline 1. Intelligence & $\begin{array}{l}\text { Exceptionally bright; } \\
\text { Excellent comprehension }\end{array}$ & & & & & & Dull; slow \\
\hline $\begin{array}{l}\text { 2. Confidence and } \\
\text { will power }\end{array}$ & $\begin{array}{l}\text { Exceptionally confident } \\
\text { and resolute }\end{array}$ & & & & & & Uncertain; hesitant \\
\hline $\begin{array}{l}\text { 3. Emotional } \\
\text { stability }\end{array}$ & Mature; balanced & & & & & & Unstable; immature \\
\hline 4. Adaptability & $\begin{array}{l}\text { Alert and highly } \\
\text { responsible }\end{array}$ & & & & & & Rigid, Inflexible \\
\hline $\begin{array}{l}\text { 5. Understanding } \\
\text { and tolerance }\end{array}$ & $\begin{array}{l}\text { Considerate and } \\
\text { Cooperative }\end{array}$ & & & & & & $\begin{array}{l}\text { Lacks ability to } \\
\text { appreciate other's } \\
\text { point of view; un- } \\
\text { sympathetic }\end{array}$ \\
\hline $\begin{array}{l}\text { 6. Appearance and } \\
\text { bearing }\end{array}$ & $\begin{array}{l}\text { Creates excellent } \\
\text { impression }\end{array}$ & & & & & & $\begin{array}{l}\text { Clumsy; } \\
\text { unimpressive }\end{array}$ \\
\hline 7. OVERALL GR & JG IN PART II & & & & & & \\
\hline
\end{tabular}

PART III

\begin{tabular}{|c|c|c|c|c|c|c|c|}
\hline \multicolumn{8}{|c|}{ ATTITUDES } \\
\hline & & A1 & $\mathrm{A}$ & $\mathrm{B}$ & $\mathrm{C}$ & $\mathrm{D}$ & \\
\hline 1. *Knowledge of Islam & Well read & & & & & & $\begin{array}{l}\text { Narrow and } \\
\text { superficial }\end{array}$ \\
\hline $\begin{array}{l}\text { 2. *Attitude towards } \\
\text { Islamic ideology }\end{array}$ & $\begin{array}{l}\text { Deeply motivated; } \\
\text { enlightened. }\end{array}$ & & & & & & $\begin{array}{l}\text { Indifferent; } \\
\text { intolerant }\end{array}$ \\
\hline $\begin{array}{l}\text { 3. Integrity } \\
\text { (a) General }\end{array}$ & Irreproachable & & & & & & Unscrupulous \\
\hline (b) Intellectual & $\begin{array}{l}\text { Honest and straight- } \\
\text { forward }\end{array}$ & & & & & & $\begin{array}{l}\text { Devious; } \\
\text { sycophant }\end{array}$ \\
\hline
\end{tabular}




\begin{tabular}{|c|c|c|c|c|c|c|c|}
\hline & & A1 & $\mathrm{A}$ & B & $\mathrm{C}$ & $\mathrm{D}$ & \\
\hline $\begin{array}{l}\text { 4. Acceptance of } \\
\text { responsibility }\end{array}$ & $\begin{array}{l}\text { Always prepared to } \\
\text { take on responsibility } \\
\text { even in difficult cases }\end{array}$ & & & & & & $\begin{array}{l}\text { Reluctant to take } \\
\text { on responsibility; } \\
\text { will avoid it } \\
\text { whenever possible }\end{array}$ \\
\hline $\begin{array}{l}\text { 5. Ability to produce } \\
\text { constructive ideas }\end{array}$ & $\begin{array}{l}\text { Full of ideas; always } \\
\text { comes up with } \\
\text { ingenious solution to } \\
\text { problems; fertile }\end{array}$ & & & & & & $\begin{array}{l}\text { Dull; has to be } \\
\text { told what to think }\end{array}$ \\
\hline 6. Foresight & $\begin{array}{l}\text { Anticipates problems } \\
\text { and plans ahead }\end{array}$ & & & & & & $\begin{array}{l}\text { Handles problems } \\
\text { only after they } \\
\text { arise }\end{array}$ \\
\hline 7. Initiative and Drive & $\begin{array}{l}\text { Bold and enterprising; } \\
\text { dynamic }\end{array}$ & & & & & & $\begin{array}{l}\text { Timid and } \\
\text { diffident }\end{array}$ \\
\hline $\begin{array}{l}\text { 8. Reliability under } \\
\text { pressure }\end{array}$ & $\begin{array}{l}\text { Imperturbable and ex- } \\
\text { ceptionally reliable at } \\
\text { all times }\end{array}$ & & & & & & $\begin{array}{l}\text { Confused and } \\
\text { easily flustered } \\
\text { even under normal } \\
\text { pressures }\end{array}$ \\
\hline 9. Judgement & $\begin{array}{l}\text { Makes consistently } \\
\text { sound proposals/ } \\
\text { decisions }\end{array}$ & & & & & & $\begin{array}{l}\text { Lacks balance and } \\
\text { consistency; } \\
\text { Immature }\end{array}$ \\
\hline $\begin{array}{ll}\text { 10. } & \text { Financial } \\
\text { Responsibility }\end{array}$ & $\begin{array}{l}\text { Exercises due care } \\
\text { discipline }\end{array}$ & & & & & & Irresponsible \\
\hline $\begin{array}{l}\text { 11. Perseverance and } \\
\text { devotion to duty }\end{array}$ & $\begin{array}{l}\text { Resolute; carries a task } \\
\text { through to the end }\end{array}$ & & & & & & $\begin{array}{l}\text { Negligent and } \\
\text { disinterested }\end{array}$ \\
\hline $\begin{array}{l}\text { 12. Relations with } \\
\text { (a) Superiors }\end{array}$ & $\begin{array}{l}\text { Cooperative; well } \\
\text { liked and trusted }\end{array}$ & & & & & & $\begin{array}{l}\text { Un-cooperative; } \\
\text { does not inspire } \\
\text { confidence }\end{array}$ \\
\hline \multirow{2}{*}{$\begin{array}{l}\text { (b) Colleagues } \\
\text { (c) Subordinates }\end{array}$} & Works well in a team & & & & & & Difficult colleague \\
\hline & $\begin{array}{l}\text { Courteous and } \\
\text { effective; inspires } \\
\text { confidence }\end{array}$ & & & & & & $\begin{array}{l}\text { Brusque and } \\
\text { Intolerant; does } \\
\text { not earn respect }\end{array}$ \\
\hline $\begin{array}{l}\text { 13. Behaviour with } \\
\text { Public }\end{array}$ & Courteous and helpful & & & & & & $\begin{array}{l}\text { Haughty; } \\
\text { unsympathetic } \\
\text { and ill behaved }\end{array}$ \\
\hline 14. & N PART III & & & & & & \\
\hline
\end{tabular}

* In case of non-mulsims the entries will refer to there own religion.

PART IV

\begin{tabular}{|c|l|l|l|l|l|l|l|}
\hline \multicolumn{9}{|c|}{ PROFICIENCY IN JOB } \\
\hline $\begin{array}{l}\text { 1. Power of Expression } \\
\text { (a) Written }\end{array}$ & $\begin{array}{l}\text { Always precise, clear } \\
\text { and well set out }\end{array}$ & & & & & & Clumsy and vague \\
\hline (b) Oral & $\begin{array}{l}\text { Comes across } \\
\text { convincingly and } \\
\text { concisely }\end{array}$ & & & & & & Ineffective \\
\hline 2. Knowledge of work & $\begin{array}{l}\text { Has a thorough grasp } \\
\text { of the knowledge } \\
\text { relevant to his job }\end{array}$ & & & & & & $\begin{array}{l}\text { Does not know } \\
\text { enough about the } \\
\text { present job }\end{array}$ \\
\hline
\end{tabular}




\begin{tabular}{|c|l|l|l|l|l|l|l|}
\hline & & A1 & A & B & C & D & \\
\hline 3. Analytical ability & $\begin{array}{l}\text { Picks out the essentials } \\
\text { without wasting time } \\
\text { on irrelevant details }\end{array}$ & & & & & & $\begin{array}{l}\text { Seldom sees } \\
\text { below the surface } \\
\text { of a problem }\end{array}$ \\
\hline $\begin{array}{l}\text { 4. Supervision and } \\
\text { Guidance }\end{array}$ & $\begin{array}{l}\text { Organises and uses } \\
\text { staff and other } \\
\text { resources effectively }\end{array}$ & & & & & & $\begin{array}{l}\text { Lacks control; } \\
\text { ineffective }\end{array}$ \\
\hline 5. Ability to take decision & $\begin{array}{l}\text { Very logical and } \\
\text { decisive }\end{array}$ & & & & & & $\begin{array}{l}\text { Indecisive; } \\
\text { vacillating }\end{array}$ \\
\hline 6. Work (a) Output & $\begin{array}{l}\text { Always up-to-date; } \\
\text { accumulates no arrears }\end{array}$ & & & & & & $\begin{array}{l}\text { Always behind } \\
\text { schedule; very } \\
\text { slow disposal }\end{array}$ \\
\hline & $\begin{array}{l}\text { Always produces work } \\
\text { of exceptionally high } \\
\text { quality }\end{array}$ & & & & & & $\begin{array}{l}\text { Generally } \\
\text { produces work of } \\
\text { poor quality }\end{array}$ \\
\hline 7. OVERALL GRADING IN PART IV & & & & & & \\
\hline
\end{tabular}

\section{PART V}

(a) Pen-picture: Please comment on any particularly strong or weak points without repeating earlier parts of the report. Also indicate the future posting considered most suitable for the officer.

(b) Counselling: Was the officer advised to improve vide instruction No. 4 during the period under report? If so, on what aspects and with what results?

(c) Assessment of performance: Please comment on how effective the officer has been in performing the duties mentioned at S. No. 9 in Part I. Also comment on the officer's contribution to the overall performance of your office/organisation especially in the light of any numerical measure e.g. examination results for teaching staff or other applicable index such as profitability, project implementation, tax collection etc. In other cases give your assessment of relative proportion of (i) routine cases (ii) complicated cases/situations (iii) policy cases/crisis situations dealt with by the officer. Also indicate whether further training is required for increasing his effectiveness and if so, in which area. 
PART VI

Comparing him with other officers of the same level and keeping in view the overall grading in Parts II, III and IV, give your general assessment of the officer by initialling the appropriate box below:

\section{(a) Overall Grading}

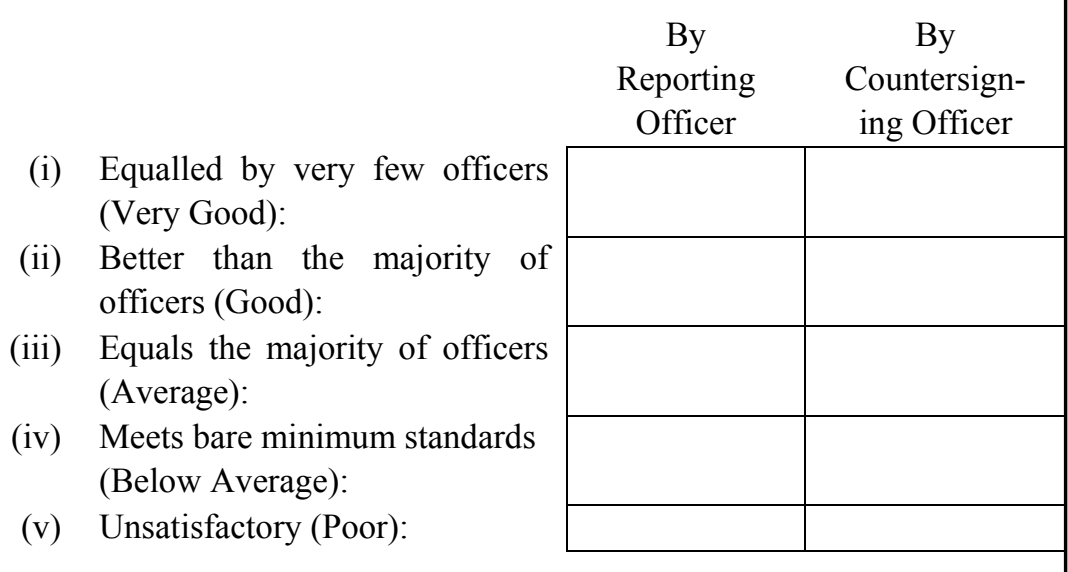

\section{(b) Fitness for promotion}

\begin{tabular}{|c|c|c|c|}
\hline & & $\begin{array}{c}\text { By } \\
\text { Reporting } \\
\text { Officer }\end{array}$ & $\begin{array}{c}\text { By } \\
\text { Countersigning } \\
\text { Officer }\end{array}$ \\
\hline (i) & Fit for accelerated promotion: & & \\
\hline (ii) & Fit for promotion in his turn: & & \\
\hline (iii) & Not yet fit for promotion: & & \\
\hline (iv) & Unlikely to progress further: & & \\
\hline
\end{tabular}

Designation

Date 


\section{PART VII}

\section{(a) REMARKS OF THE COUNTERSIGNING OFFICER}

Please report on the aspects not touched upon by the Reporting Officer. If you disagree with the assessment of the Reporting Officer, please give reasons therefor. You should also indicate how frequently you have seen work of the officer reported upon. If the officer has been assessed fit for promotion, would you be prepared to accept him in the higher grade. If no, please give your reasons.

Name

Signature

(Capital letters)

Designation.

Date

(b) REMARKS OF THE SECOND COUNTERSIGNING OFFICER (IF ANY)

Name

Signature

(Capital letters)

Designation

Date

\section{PART VIII}

1. Adverse remarks, if any, communicated vide

Date

2. Decision on representation, if any 


\section{INSTRUCTIONS FOR FILLING UP THE ACR FORMS}

1. (i) ACR is the most important record for the assessment of an officer. At the same time, the quality of the ACR is a measure of the competence of the Reporting Officer and the Countersigning Officer. It is, therefore, essential that utmost care is exercised by all Reporting and Countersigning Officers.

(ii) The Reporting and Countersigning Officer should be

(a) as objective as possible; and

(b) clear and direct, not ambiguous or evasive in their remarks.

(iii) The over-riding importance of Part IV should be clearly understood in the overall grading.

(iv) Over-rating should be eschewed by all Reporting/Countersigning Officers.

(v) Vague impressions based on inadequate knowledge or isolated incidents should be avoided.

2. The forms are to be filled in duplicate. Part I will be filled by the officer being reported upon and should be typewritten. Parts II to VI will be filled by the Reporting Officer, and Part VII by the Countersigning Officers. Both the Reporting Officer and the Countersigning Officer should give their assessment of the officer reported upon in respective boxes in Part V. The Ministry/Division/Department concerned will fill Part-VIII, if any adverse remarks are recorded in the report.

3. Assessment in the ACR should be confined to the work done by the officer reported upon during the period covered by the report.

4. The Reporting Officer is expected to counsel the officer being reported upon about his/her weak points and advise him/her on how to improve. Adverse remarks should normally be recorded when the officer fails to improve despite counselling.

5. The ACR form should be filled in a neat and tidy manner. Cuttings/erasures should be avoided and where made, must be initialled.

6. The ratings in Parts II, III, IV and VI should be recorded by initialling the appropriate box.

7. For uniform interpretation of qualities etc. listed in Parts II, III and IV, the two extreme shades are mentioned against each item. For example an 'exceptionally bright' officer with 'excellent comprehension' will be rated 'A1' in 'Intelligence' (box-I of Part II). A dull and slow officer will merit a ' $\mathrm{D}$ ' rating. A, B and $\mathrm{C}$ ratings will denote shades between the above two extremes.

8. The ratings should be clear and given in one of the boxes provided for the purpose in Parts II, III, IV \& VI. Do not grade an officer between the two shades i.e. between 'Very Good' and 'Good' or 'Good' and 'Average' or 'Average' and 'Below Average'.

9. The Countersigning Officer should weigh the remarks of the Reporting Officer against his/her personal knowledge of the officer being reported upon, compare him/her with other officers of the same grade working under different Reporting Officers but under the same Countersigning Officer, and then give his/her overall assessment in Part VI and remarks in Part VII (a). In certain categories of cases remarks of a Second Countersigning Officer may also be required to be recorded. The Establishment Division will identify such cases from time to time and also designate an officer as the Second Countersigning Officer for each category. The Second Countersigning Officer will record his remarks in Part VII (b).

10. If the Countersigning Officer differs with the grading or remarks given (in parts other than Part VI) by the Reporting Officer, he/she should score it out and give his/her own grading in red ink. In Part VI he/she is required to give his/her own assessment in addition to that of the Reporting Officer.

11. The Countersigning Officer should underline, in red ink, the remarks which in his opinion are adverse and should be communicated to the officer reported upon. 


\section{REFERENCES}

Boeninger, Edgardo (1992) Governance and Development Issues and Constraints. Proceedings of the World Bank Annual Conference on Development Economics.

Bhatt, Anil, and Carino V. Ledwina et al. (1987) Building from Below: Local Initiatives for Decentralised Development in Asia and Pacific. KAS and APDC, pp. 17-23.

Edralin, Josefa S. (1996-97) The New Local Governance and Capacity—Building: A Strategic Approach Examples from Africa, Asia and Latin America. Regional Development Studies 3: Winter. p. 109.

Kiggundu, N. Moses (1989) Managing Organisation in Developing Countries: An Operation and Strategic Approach. Kumarian Press

Leftwich, Adrian (1993) Governance, Democracy and Development in the Third World. Third World Quarterly 14:3.

Sharitz, M. Jay, and Ott. Steven J. (1987) Classics of Organisation Theory. Pacific Grove, California: Brook/Cole Publishing Co.

World Bank (1993) The East Asian Miracle: Economic Growth and Public Policy. Oxford University Press. (World Bank Policy Research Report.)

Wright, Peter, Kroll M. J., and Parnell John (1996) Strategic Management: Cases and Concept. N.J. Prentice Hall. 188-191. 


\section{Comments}

Ms Seemi Waheed's paper, "Capacity Building for Public Sector Organisations", is an interesting and timely paper. The underlying argument is that there is need for a new "model" for capacity building in public sector organisations. Capacity building, as she rightly points out, is part of the literature on governance, good governance, in fact. After reviewing some of the major works on capacity building, particularly those of Boeninger and Cohen. Ms Waheed constructs a model (Fig. 1) comprising largely conceptual and theoretical concerns. In this model, mission statement, i.e., organisational mission statement is a basic component. In fact, she goes on to claim that: "the mission statement is the independent variable on which all the other variables and sub-variables are dependent. It is assumed that once the organisation formulates clear mission statement, goals and objectives it would be relatively easier to develop appropriate structure and HRMS (Human Resource Management System) to achieve goals". Here, I have no problem with her emphasis on the mission statement. In fact, I agree with her. However, I fail to understand as to why she insists on calling the mission statement an "independent variable on which all the other variables and sub-variables are dependent". In my opinion, other variables will cease to be independent variables if they are "dependent" on the mission statement. Independent variables are independent variables because they are independent of each other. Only then they can possibly explain a 'dependent variable', such as capacity building, in the present case.

In highlighting the nature and importance of the mission statement, Ms Waheed offers a variety of suggestions as to what it shall imply; what kind of goals will follow from it, and what type of objectives will ensue. This is fine. However, there is a rub. The emphasis all along is on the managerial input functions. There is little mention of outputs. In this sense, the whole argument is more about management than development and change. And although Ms Waheed talks about "work ethics" for promotion of good governance, in the context of the mission statement, she does not quite define or build on these "ethics". The emphasis seems to be on the job well done rather than on vocation, duty and service, which are increasingly being recognised as essential roles in the new field of development administration. I assume work ethics must also include an attitudinal shift in public sector organisations from preoccupation with rank, status and privilege to respect towards the common man. A common man's viewpoint needs to be understood and taken into account in arriving at decisions affecting his life and future. Indeed, a harmonious relationship between the rulers and the ruled is an integral part of good governance. 
In her discussion with regard to the structure of public organisations, Ms Waheed makes a very pertinent point. She stresses that government structures are generally monolithic in character, irrespective of what "business" particular organisation is pursuing. One way out, she suggests, is "decentralisation" which is right and is the subject of much discussion in Pakistan today. But then, I believe, decentralisation should not be the end of administrative organisations. It must rather be means to an effective developmental bureaucracy, which is both responsible and accountable to the people and is committed to the mammoth task of nation-building.

Interestingly, Ms Waheed does not propose any measures to cut back the scope of government activities through privatisation and private solutions, especially in education, health, population, and other social sectors. Indeed, there is no proposal suggesting reduction in the nature and scope of the centralised administrative apparatus in the public sector. This omission is all the more significant given the fact that the so-called "de-bureaucratisation" is the dominant trend of the 1990s. In terms of performance evaluation and compensation, I agree with Ms Waheed that salaries in the public sector are considerably low compared to the private sector. There must be rewards and incentives for good work, and, here, I also agree with her that it must be judged thorough the "achievement of objectives". But, I also feel that there must be punishment, too, for non-performance. This will discourage the trend of evasions and delay in the implementation of major decisions. Part of the problem may be 'cultural'. Although senior government employees are recruited on merit and competition, some remain tied to their formative influences, such as family, kinship, region, ethnicity, etc. That may make it difficult for them to take timely decisions. But non-performance is not the only problem. There is a more serious problem of misuse of powers, especially discretionary powers given to the employees to regulate state and social sectors. This increased regulatory authority creates opportunities for making money, and hence corrupt practices and corruption. But it cannot be denied that corruption can exist only if there is someone willing to corrupt. The public demands a high standard of integrity in public organisations and bureaucracy, but, at the same time, condones unethical and immoral practices among themselves. The materialistic way of life has a tendency to corrupt all.

This brings us to the issue of "accountability", especially in the context of public policy and administration. Generally, officials are considered accountable to the extent that they are legally required to answer for their policies and actions. In other words, accountability remains confined to the legality of administrative actions. Other aspects of accountability, such as organisational and professional behaviour, financial prudence and correctness of decisions are not taken into account. It is only when we look at accountability in its totality, including administrative, professional, legal, financial and moral aspects, that we can hope to secure a good public organisation and good government. 
At the end of her paper, Ms Seemi Waheed concedes that her model for capacity building has a number of "constraints" to contend with, particularly in a developing country situation, which must obviously include Pakistan. One of them pertains to interference in routine (or not so routine) matters by political leaders. The point is well taken. The experience of last 50 years bears testimony to it. Either the public organisations responded to political demands or the politicians simply bypassed the established administrative systems and procedures and created their own networks to achieve their goals. Public organisations thus became a source of administrative mismanagement, economic ills and political blundering. The result was despair and distrust of the people who charged that both politicians and administrators were not capable of running the machinery of government properly. The separation of politics from administration is embedded in the theory of public administration. It must remain so in practice as well.

Sikandar Hayat

Quaid-i-Azam University,

Islamabad. 